\title{
Dietary Content and Evaluation of Metals in Four Types of Tea (White, Black, Red and Green) Consumed by the Population of the Canary Islands
}

Gonzalez-Weller D*, Rubio C, Gutiérrez AJ, Pérez B, Hernández-Sánchez C, Caballero JM, Revert C and Hardisson A

Department of Public Health and Toxicology, University of La Laguna, 38071, La Laguna, Tenerife, Spain

\begin{abstract}
Objective: The aim of this study was to analyze the contents of $\mathrm{Cd}, \mathrm{Co}, \mathrm{Cr}, \mathrm{Cu}, \mathrm{Fe}, \mathrm{Mg}, \mathrm{Ni}, \mathrm{Pb}, \mathrm{Zn}$ in samples of four types of tea (Camellia sinensis) consumed in the Canary Islands: white, black, red and green tea, in order to determine their intake through consumption.
\end{abstract}

Methods: A total of 80 samples (20 of each type of tea) were analyzed by ICP-OES.

Results: The highest concentrations of $\mathrm{Cd}$, $\mathrm{Co}, \mathrm{Mg}, \mathrm{Pb}$ and $\mathrm{Zn}$ were found in samples of white tea, those of $\mathrm{Cr}, \mathrm{Fe}$ and $\mathrm{Ni}$ in the red tea, and those of $\mathrm{Cu}$ in green tea. While the lowest levels of $\mathrm{Cd}$, Co, $\mathrm{Fe}, \mathrm{Pb}$ and $\mathrm{Zn}$ were found in black tea, those of $\mathrm{Cr}, \mathrm{Mg}$ and $\mathrm{Ni}$ in the green tea, and those of $\mathrm{Cu}$ in the white tea.

Conclusion: The calculated intakes of each metal (assuming the consumption of a cup of tea $2 \mathrm{~g} /$ day) shows that $\mathrm{Cr}, \mathrm{Cu}, \mathrm{Fe}, \mathrm{Mg}$ and $\mathrm{Zn}$ make a negligible contribution to the RDI, and the same applies to $\mathrm{Cd}$ to the PTMI and Pb to the PTWI.

Keywords: Metals; ICP-OES; Dietary assessment; Spanish population; Canary Islands

\section{Introduction}

Tea or blends of tea are understood to be the buds, shoots and young leaves of the shrub Camellia sinensis (Theaceae) [1]. This shrub of Asian origin has been cultivated since ancient times [2] and is currently being grown in much of Asia, Africa, Turkey and other countries. The different types of tea are determined by a number of factors such as the time of harvest (depending on leaf development), the processing method, drying, roasting and fermentation processes [3].

The consumption of tea has been estimated to be about 18 to 20 billion cups of tea a day worldwide, meaning that it is the second most consumed beverage after water in the world $[4,5]$.

Note that the four types of tea which are the objects of this study (white, black, red and green), have beneficial properties for human health, thus, black tea has antioxidant properties [6], hepatoprotective [7], antiarterioesclerotic [8], lipolytic, thermogenic $[9,10]$, and anticarcinogenic [11]. Antioxidant properties are attributed to green tea [12-14], antiarterioesclerotic [15], hepatoprotective [16], lipolytic, thermogenic $[17,18]$, anticarcinogenic $[19,20]$ and reducing platelet aggregation [21]. White tea has neuroprotective properties [22,23], anticarcinogenic $[24,25]$, protection from ultraviolet radiation when used topically [26] and inhibition of acetylcholinesterase [27]. Red tea has antioxidant features [28], antiarterioesclerotic [8], lipolytic, thermogenic [29] and anticarcinogenic [30].

Although metals are perhaps the oldest known most toxic agents, interest in them has not declined and knowledge concerning their potential toxic effects and mechanisms of action has increased in recent years [31]. Metals such as iron, copper and zinc are considered essential minerals for humans, although high concentrations could be potentially toxic [32-34]. Heavy metals, like lead and cadmium, are regarded as toxic environmental contaminants in food [35]. Compared with other toxic substances, heavy metals are considered to be most damaging to living systems. Food and water are the primary source of these metals for humans $[36,37]$.
The main and most important feature of cobalt is that it is an integral part of a family of compounds called cobalamins; the most important of which are vitamin B12 and coenzyme B12. Coenzyme B12 is used as a cofactor for many enzymes, among which the mutases, diol dehydratase (deaminase) and ribonucleotide reductases are the most notable [38].

Chromium is an essential mineral that seems to play a role in carbohydrate metabolism as a component of the glucose tolerance factor, involved in cardiovascular risk and the metabolic syndrome, as well as its antioxidant properties. The normal oxidation state in biological tissues is $\mathrm{Cr}$ (III), which is the nutritionally essential form of Cr for animals and humans $[39,40]$.

Copper is required for the catalytic activities of many metalloenzymes such as cytochrome $\mathrm{C}$ oxidase, superoxide dismutase, dopamine $\beta$-hydroxylase, lysyl oxidase, and tyrosinase, apart from which it acts as a cofactor in various redox enzymes, in mitochondrial respiration, iron absorption, and elastin synthesis. Copper has recently been identified as a factor in prion disease prevention [41,42].

The key functions of iron include oxygen transport in blood and muscle tissue (through haemoglobin and myoglobin), taking partalong with copper-in redox processes, and iron has an important role

*Corresponding author: Gonzalez-Weller D, Department of Toxicology, University of La Laguna, 38071, La Laguna, Tenerife, Spain, Tel: +34-616-992801; Fax: +34922-626497; E-mail: dgonzal@ull.es

Received September 29, 2015; Accepted October 16, 2015; Published October 19, 2015

Citation: Gonzalez-Weller D, Rubio C, Gutiérrez AJ, Pérez B, Hernández-Sánchez C, et al.(2015) Dietary Content and Evaluation of Metals in Four Types of Tea (White, Black, Red and Green) Consumed by the Population of the Canary Islands. Pharm Anal Acta 6: 428. doi:10.4172/21532435.1000428

Copyright: $\odot 2015$ Gonzalez-Weller D, et al. This is an open-access article distributed under the terms of the Creative Commons Attribution License, which permits unrestricted use, distribution, and reproduction in any medium, provided the original author and source are credited. 
Citation: Gonzalez-Weller D, Rubio C, Gutiérrez AJ, Pérez B, Hernández-Sánchez C, et al.(2015) Dietary Content and Evaluation of Metals in Four Types of Tea (White, Black, Red and Green) Consumed by the Population of the Canary Islands. Pharm Anal Acta 6: 428. doi:10.4172/21532435.1000428

Page 2 of 10

in the biosynthesis of certain proteins like collagen and elastin [42,43].

Magnesium is a crucial element in the generation and use of adenosine triphosphate, and is required for oxidative phosphorylation. It is involved in energy metabolism, glucose utilization, protein synthesis, synthesis and degradation of fatty acids, ATPase functions, hormonal reactions, neuromuscular transmission signalling and cardiovascular health. Magnesium is also associated with the maintenance of cellular ionic balance through its relationsips with sodium, potassium and calcium [44-46].

Although nickel is an essential trace element for various animal species, its biochemical role in humans and higher animals has not been demonstrated. However, it may serve as a cofactor or structural component of several metalloenzymes with a variety of functions (hydrolysis, redox reactions) and in gene expression [34,47].

Zinc is involved in biochemical processes, such as cell respiration and the use of oxygen by cells, both DNA and RNA synthesis, the preservation of the cell membrane integrity, and the elimination of free radicals, a process executed through a cascade of enzymatic systems $[42,48]$.

Cadmium and lead are not essential for the human organism [34]. Cadmium has a long residence time in human tissues (10-40 years), especially in the kidneys and liver, where it bio-accumulates [49,50] and its toxic effects are noticeable in various ways. It can interfere with some of the organism's enzymatic reactions, substituting zinc and other metals, manifesting its action in several pathological processes such as renal dysfunctions, hypertension, arteriosclerosis, inhibition of growth, damage in the nervous system, bone demineralisation and endocrine disruption [37]. The main toxic effect of lead is the dysfunction of the nervous system in the foetus and infants. In adults, lead causes: adverse blood effects, reproductive dysfunctions; damage to the gastrointestinal track; nephropathies; damage to the central as well as the peripheral nervous system and interferences in the enzymatic systems that synthesise the HEME group [37].

Therefore, and assuming that food consumption is the main route of exposure of the general population to metals, that tea is a highly consumed food, that its metallic levels and the intake these are responsible for is unknown in the Canary islands, the main objective of this work has been to determine the concentrations of $\mathrm{Cd}, \mathrm{Co}, \mathrm{Cr}, \mathrm{Cu}$, $\mathrm{Fe}, \mathrm{Mg}, \mathrm{Ni}, \mathrm{Pb}$ and $\mathrm{Zn}$ in tea (white tea, black, red and green) and to discover the dietary intakes resulting from its consumption.

\section{Material and Methods}

\section{Samples}

A total of 80 samples of different brands of tea sold on the island of Tenerife were analyzed: 20 black tea, 20 green tea, 20 red tea and 20 white tea. The samples were purchased in supermarkets, health food shops and pharmacies for four months (between January and April 2014).

Before sample preparation, all laboratory materials were washed with Acationox laboratory cleaning agent (Merck, Darmstadt, Germany) to avoid contamination and eliminate any possible trace metals. They were then kept in $5 \%$ nitric acid for $24 \mathrm{~h}$ and subsequently washed with Milli-Q (Millipore, Milford, MA) quality water.

After collection and classification, the food samples were homogenized, preserved at $-18^{\circ} \mathrm{C}$ and analysed within 2 months.

\section{Determination of metals}

Ten grams of homogenized sample of each type of tea were weighed in triplicate in porous porcelain capsules on scales PB153-S / FACT (Mettler Toledo, Switzerland). The capsules with the samples were then subjected to drying in an oven (Selecta, Spain) at $60-70^{\circ} \mathrm{C}$ for 12-14 hours. Afterwards, the samples were placed in a muffle furnace (Nabertherm ${ }^{\circ}$, Germany) and the temperature was gradually increased $\left(50^{\circ} \mathrm{C} /\right.$ hour $)$ until it reached $425 \pm 15^{\circ} \mathrm{C}$, this temperature was maintained for 18-24 hours to destroy the organic matter in the sample. The white ashes obtained by this procedure were dissolved in $1.5 \%$ nitric acid to a final volume of $25 \mathrm{ml}$.

The digested samples were transferred into polyethylene containers and stored for a maximum of one month until analysis. The elements in the samples were determined by ICP-OES using a Thermo Scientific iCAP 6000 series spectrometer (Waltham, MA, USA). This reference technique for metal determination is highly sensitive with excellent data reproducibility [34]. The settings were as follows: approximate RF power, $1.2 \mathrm{~kW}$; gas flow (nebulizer flow; auxiliary flow), $0.5 \mathrm{~L} / \mathrm{min}$; pump rate, $50 \mathrm{rpm}$; stabilization time $0 \mathrm{~s}$. All analyzes were performed in duplicate.

The quality controls used in this work were chosen by the criterion of method accuracy. This was established by the average recovery obtained with reference material measured under reproducible conditions. The reference materials SRM 1515 Apple Leaves and SRM 1573a Tomato Leaves from the National Institute of Standards and Technology (NIST) were used. Recovery rates obtained from the reference materials were over $94.4 \%$ (Table 1). Instrumental detection and quantification limits in terms of reproducibility were calculated as three and ten times the standard deviation (SD) resulting from the analysis of 15 targets of acid digest [51] and are shown in table 2.

\section{Statistical analysis}

The SPSS 22.0 software (IBM, USA) was used for the statistical analysis of the results. The normality of the data was checked using the Kolmogorov-Smirnov and Shapiro-Wilk [52], while the Levene test was used to check homogeneity of variance [53]. Given that the results of these tests showed neither normality nor homogeneity of variances, it was decided to perform a non-parametric statistical test (Kruskal-Wallis) to check whether there were significant differences between the studied samples and the Mann Whitney $U$ test to clarify between which types of tea there were differences. $P$ values $<0.05$ were considered statistically significant.

\section{Results and Discussion}

The mean concentrations of the metals which were the object of this study (wet weight) and their corresponding standard deviation are shown in Table 3.

Cadmium concentrations ranged from $38.20 \mathrm{mg} / \mathrm{kg}$ in white tea and the levels in black tea were below the detection limit $(<2.5 \mathrm{mg} /$ $\mathrm{kg}$ ). The maximum concentration for cobalt of this element, $0.70 \mathrm{mg} /$ $\mathrm{kg}$, was found in white tea and the minimum, $0.44 \mathrm{mg} / \mathrm{kg}$, was in black tea, although very similar to those in the red and black teas, 0.45 and $0.46 \mathrm{mg} / \mathrm{kg}$, respectively. In the case of chromium, $2.56 \mathrm{mg} / \mathrm{kg}$ was the maximum content which was found in the red tea and the minimum was $0.26 \mathrm{mg} / \mathrm{kg}$ which was found in the green tea. The highest copper content was found in the green tea $(8.40 \mathrm{mg} / \mathrm{kg})$ and the lowest in the white tea $(5.46 \mathrm{mg} / \mathrm{kg})$. With respect to iron, the red and black teas had the greatest and least amounts of this element $(227.43$ and $90.00 \mathrm{mg} / \mathrm{kg}$, respectively). The highest concentration of magnesium was detected in the white and that of nickel in the red tea, $(142.33 \mathrm{mg} / \mathrm{kg}$ of magnesium 
Citation: Gonzalez-Weller D, Rubio C, Gutiérrez AJ, Pérez B, Hernández-Sánchez C, et al.(2015) Dietary Content and Evaluation of Metals in Four Types of Tea (White, Black, Red and Green) Consumed by the Population of the Canary Islands. Pharm Anal Acta 6: 428. doi:10.4172/21532435.1000428

Page 3 of 10

\begin{tabular}{|c|c|c|c|c|}
\hline Reference material & Element & Certified value ${ }^{a, b}(\mathrm{mg} / \mathrm{kg})$ & Obtained value $^{\mathrm{a}}(\mathrm{mg} / \mathrm{kg})$ & Recovery (\%) \\
\hline \multirow[t]{5}{*}{ SRM 1515 Apple Leaves } & $\mathrm{Mg}$ & $0.271 \pm 0.008^{c}$ & $0.281 \pm 0.014$ & 103.8 \\
\hline & $\mathrm{Cu}$ & $5.64 \pm 0.24$ & $5.55 \pm 0.65$ & 98.4 \\
\hline & $\mathrm{Ni}$ & $0.91 \pm 0.12$ & $0.88 \pm 0.48$ & 96.8 \\
\hline & $\mathrm{Pb}$ & $0.470 \pm 0.024$ & $0.45 \pm 0.032$ & 95.7 \\
\hline & $\mathrm{Zn}$ & $12.5 \pm 0.3$ & $12.4 \pm 0.23$ & 99.2 \\
\hline \multirow[t]{4}{*}{ SRM 1573a Tomato Leaves } & $\mathrm{Cd}$ & $1.52 \pm 0.04$ & $1.43 \pm 0.1$ & 94.4 \\
\hline & $\mathrm{Cr}$ & $1.99 \pm 0.06$ & $1.92 \pm 0.09$ & 96.6 \\
\hline & Co & $0.57 \pm 0.02$ & $0.54 \pm 0.07$ & 94.1 \\
\hline & $\mathrm{Fe}$ & $368 \pm 7$ & $375 \pm 9$ & 101.8 \\
\hline
\end{tabular}

aMean \pm standard deviation

${ }^{\mathrm{b}}$ Confidence interval: $95 \%$

${ }^{\circ}$ Concentration in mass fraction (\%)

Table 1: Quality control of the method.

\begin{tabular}{|c|c|c|}
\hline Element and wavelength & Detection limit (LOD) (mg/l) & Quantification limit (LOQ) (mg/l) \\
\hline $\operatorname{Cd}(226.5 \mathrm{~nm})$ & 0.0003 & 0.001 \\
\hline $\operatorname{Co}(228.6 \mathrm{~nm})$ & 0.0006 & 0.002 \\
\hline $\operatorname{Cr}(267.7 \mathrm{~nm})$ & 0.003 & 0.008 \\
\hline $\operatorname{Cu}(327.3 \mathrm{~nm})$ & 0.004 & 0.012 \\
\hline $\operatorname{Fe}(259.9 \mathrm{~nm})$ & 0.003 & 0.009 \\
\hline $\operatorname{Mg}(279.1 \mathrm{~nm})$ & 0.583 & 1.943 \\
\hline $\operatorname{Ni}(231.6 \mathrm{~nm})$ & 0.0007 & 0.003 \\
\hline $\operatorname{Pb}(220.3 \mathrm{~nm})$ & 0.0003 \\
\hline $\operatorname{Zn}(206.2 \mathrm{~nm})$ & 0.002 \\
\hline
\end{tabular}

Table 2: Detection and quantification limits.

\begin{tabular}{|c|c|c|c|c|}
\hline & White & Black & Red & Green \\
\hline Cd $(\mu \mathrm{g} / \mathrm{Kg}$, wet weight) & $38.20 \pm 50.12$ & $<\mathrm{LOQ}^{1}$ & $31.00 \pm 27.15$ & $7.75 \pm 13.88$ \\
\hline Co $(\mathrm{mg} / \mathrm{Kg}$, wet weight) & $0.70 \pm 0.095$ & $0.44 \pm 0.09$ & $0.45 \pm 0.16$ & $0.46 \pm 0.20$ \\
\hline $\mathrm{Cr}$ (mg/Kg, wet weight) & $1.12 \pm 0.38$ & $0.38 \pm 0.15$ & $2.56 \pm 0.54$ & $0.26 \pm 0.08$ \\
\hline $\mathrm{Cu}$ (mg/Kg, wet weight) & $5.46 \pm 1.32$ & $5.64 \pm 1.19$ & $7.76 \pm 1.33$ & $8.40 \pm 4.5$ \\
\hline $\mathrm{Fe}$ (mg/Kg, wet weight) & $90.00 \pm 28.85$ & $33.29 \pm 13.72$ & $227.43 \pm 68.39$ & $65.66 \pm 26.77$ \\
\hline Mg (mg/Kg, wet weight) & $142.33 \pm 103.22$ & $58.03 \pm 38.53$ & $99.99 \pm 41.85$ & $38.13 \pm 19.79$ \\
\hline Ni (mg/Kg, wet weight) & $3.38 \pm 0.86$ & $2.82 \pm 0.53$ & $3.87 \pm 0.48$ & $2.31 \pm 0.54$ \\
\hline $\mathrm{Pb}(\mu \mathrm{g} / \mathrm{Kg}$, wet weight) & $154.05 \pm 183.74$ & $26.00 \pm 25.93$ & $102.40 \pm 47.51$ & $38.90 \pm 22.92$ \\
\hline Zn (mg/Kg, wet weight) & $7.35 \pm 1.60$ & $5.04 \pm 0.80$ & $7.20 \pm 1.06$ & $5.16 \pm 1.11$ \\
\hline
\end{tabular}

${ }^{1} \mathrm{LOQ}$ : Quantification limit

Table 3: Cd, Co, Cr, Cu, Fe, Mg, Ni, Pb and $\mathrm{Zn}$ contents in the different types of tea: mean \pm standard deviation.

and $3.87 \mathrm{mg} / \mathrm{kg}$ of nickel), but the lowest amounts of these metals were found in the green tea ( 38.13 and $2.31 \mathrm{mg} / \mathrm{kg}$ respectively). Finally, as for lead and zinc, the largest quantities of both these elements were observed in the white tea $(154.05 \mathrm{mg} / \mathrm{kg}$ and $7.35 \mathrm{mg} / \mathrm{kg}$, respectively) and the smallest quantities in the black tea $(26.00 \mathrm{mg} / \mathrm{kg}$ and $5.04 \mathrm{mg} /$ $\mathrm{kg}$, respectively).

Therefore, cadmium, cobalt, magnesium, lead and zinc were found to be present in the greatest quantities in the samples of white tea, while chromium, iron and nickel had the greatest presence in the red tea, and copper in the green tea. The lowest levels of cadmium, cobalt, iron, lead and zinc were observed in the black tea, chromium, magnesium and nickel levels were lowest in the green tea and copper in the white tea.

It is noteworthy that, in some of the analyzed teas, the variability of the results is high. However, this variability in biological samples is considered normal, since the metal content in foods, both plants and animals, depends on various factors ranging from environmental conditions to the production and processing methods [54].

Significant differences were observed for the metal concentrations depending on the type of tea. In the case of cadmium, white tea and red tea had significantly greater differences $(\mathrm{p}<0.05)$ compared to black tea and green tea. In the case of cobalt, white tea differed significantly $(\mathrm{p}<0.05)$ from black, red and green tea. As regards chrome, red tea was different from white tea, and they in turn differed from black tea and green tea $(\mathrm{p}<0.05)$. With regard to copper content, this was significantly higher $(\mathrm{p}<0.05)$ in red and green tea when compared to black and white tea, and similar to that observed for iron, although in this case, red tea was differentiated from black tea, and both of these in turn from white tea and green tea $(p<0.05)$. As for magnesium concentrations, those in the white tea differed from those in the red tea, and both of them differed from the black and green teas $(p<0.05)$. Red tea had 
Citation: Gonzalez-Weller D, Rubio C, Gutiérrez AJ, Pérez B, Hernández-Sánchez C, et al.(2015) Dietary Content and Evaluation of Metals in Four Types of Tea (White, Black, Red and Green) Consumed by the Population of the Canary Islands. Pharm Anal Acta 6: 428. doi:10.4172/21532435.1000428

Page 4 of 10

significantly higher concentrations of nickel $(\mathrm{p}<0.05)$ with respect to the white, green and black teas. In case of lead, red tea and white tea are significantly differentiated by their higher lead contents $(\mathrm{p}<0.05)$ with respect to the black and green teas and finally the zinc contents in the white tea and the red tea were significantly differentiated from the black tea and the green tea $(\mathrm{p}<0.05)$.

A correlation study was also performed using the Pearson correlation test, yielding the following positive correlations between elements: Cr / Fe, Cr / Ni, Cr / Zn, Cr / Mg, Cr / Cd, Co / Ni, Co / Zn, $\mathrm{Co} / \mathrm{Mg}, \mathrm{Fe} / \mathrm{Cr}, \mathrm{Fe} / \mathrm{Cu}, \mathrm{Fe} / \mathrm{Ni}, \mathrm{Fe} / \mathrm{Zn}, \mathrm{Fe} / \mathrm{Cd}, \mathrm{Ni} / \mathrm{Zn}, \mathrm{Ni} / \mathrm{Mg}, \mathrm{Ni}$ / Cd, $\mathrm{Ni} / \mathrm{Pb}, \mathrm{Zn} / \mathrm{Mg}, \mathrm{Zn} / \mathrm{Cd}, \mathrm{Zn} / \mathrm{Pb}, \mathrm{Mg} / \mathrm{Cd}, \mathrm{Mg} / \mathrm{Pb}, \mathrm{Cd} / \mathrm{Pb}$ and the only negative correlation was between $\mathrm{Co} / \mathrm{Cu}$ (Table 4).

The comparison of the concentrations of metals in this study with those of other authors, could only be carried out in the case of black and green tea, because in the cases of white and red tea no references from other studies were found to perform the said comparison. Table 5 shows the comparison of the metal concentrations in black tea obtained in this study with other previous studies of metals in black tea. It is observed that the cadmium levels obtained in the present study $(<0.0025 \mathrm{mg} / \mathrm{kg})$, are lower compared to those obtained by the other studies, particularly with regard to teas from Saudi Arabia $(1.1 \mathrm{mg} /$ $\mathrm{kg})$ [3]. Cobalt levels $(0.44 \pm 0.09 \mathrm{mg} / \mathrm{kg})$ are consistent with other studies, except for the case of tea from Saudi Arabia $(10.98 \mathrm{mg} / \mathrm{kg})$ [3] and Turkey $(14.5 \pm 7.1 \mathrm{mg} / \mathrm{kg})$ [56], which are in the order of 25 and 33 times higher, respectively. The values of chromium $(0.38 \pm 0.15 \mathrm{mg} /$ $\mathrm{kg}$ ) are much lower than those observed by other studies, and were up to 34 times lower than the tea from Turkey $(13.0 \pm 1.7 \mathrm{mg} / \mathrm{kg})[56]$. The concentration of copper in the present study $(5.64 \pm 1.19 \mathrm{mg} / \mathrm{kg})$ is about 18 times greater than that reported in the study on teas produced in Taiwan $(7.92 \mathrm{mg} / \mathrm{kg})$ [57], lower than the other works, and was up to 5 times lower than the value reported by Matsuura et al., in 2001 in Japan $(27.7 \pm 0.7 \mathrm{mg} / \mathrm{kg})$. The iron levels $(33.29 \pm 13.72 \mathrm{mg} / \mathrm{kg})$ are only greater than those from Taiwan $(0.9 \mathrm{mg} / \mathrm{kg})$, about 37 times higher, but lower than for the other authors. As regards magnesium concentrations, the levels of the present study $(58.03 \pm 38.53 \mathrm{mg} / \mathrm{kg})$ are lower than those described by Matsuura et al., in 2001, in Japan (2070 $\pm 30 \mathrm{mg} / \mathrm{kg}$ ) and Shen and Chen, in 2008, in Taiwan $(135.3 \mathrm{mg} / \mathrm{kg})$. In the case of nickel, the levels of the study here $(2.82 \pm 0.53 \mathrm{mg} / \mathrm{kg})$ are in line with other authors, except for Saudi Arabian tea $(16.8 \mathrm{mg} / \mathrm{kg})$ and Turkish tea $(23.3 \pm 9.6 \mathrm{mg} / \mathrm{kg})$. The lead levels reported in the present work are low $(0.026 \pm 0.0259 \mathrm{mg} / \mathrm{kg})$, particularly when compared with those of Turkish tea $(17.9 \pm 7.1 \mathrm{mg} / \mathrm{kg}$ ) [56] (approximately 688 times higher). The same applies in the case of zinc, the level reported in the teas by Narin et al., in 2004, Turkey $(129.0 \pm 12.9 \mathrm{mg} / \mathrm{kg})$ are much higher than those found here $(5.04 \pm 0.81 \mathrm{mg} / \mathrm{kg})$.

The comparisons of the metal concentrations in green tea obtained in this study with those of previous studies are shown in Table 6 . The levels of cadmium and cobalt found here are very similar to those of other studies. The chromium concentration in Thai tea $(1,476 \mathrm{mg} / \mathrm{kg})$ [32] is 6 times higher than those consumed in the Canary Islands $(0.26$ $\pm 0.08 \mathrm{mg} / \mathrm{kg}$ ). The results for copper are similar, where the copper levels reported by Nookabkaew et al., in 2006, also in Thailand (15.20 $\mathrm{mg} / \mathrm{kg}$ ), are 2 times higher than those consumed in the Canary Islands $(8.40 \pm 4.5 \mathrm{mg} / \mathrm{kg})$ although Taiwanese tea $(0.4 \mathrm{mg} / \mathrm{kg})$ [57] has copper concentrations which are 21 times lower. The iron concentration found in the present study $(65.66 \pm 26.77 \mathrm{mg} / \mathrm{kg})$ is much higher than that reported by Shen and Chen in 2008 in Taiwan $(0.6 \mathrm{mg} / \mathrm{kh})$, but lower than that of other authors. The magnesium levels in the study (38.13 \pm $19.79 \mathrm{mg} / \mathrm{kg}$ ) are much lower than those from Thailand [32] and Japan
[59] which were 2017 and $2200 \pm 60 \mathrm{mg} / \mathrm{kg}$, respectively. The nickel concentration reported here is similar to that of other authors, with that of lead being lower. Specifically, the lead levels reported in the teas from Thailand [32] are 103 times higher than those found in the present study $(3.930 \mathrm{mg} / \mathrm{kg}$ versus $0.03890 \pm 0.02292)$. The zinc levels found here $(5.16 \pm 1.11 \mathrm{mg} / \mathrm{kg})$ are similar to those described by Shen and Chen, 2008, in Taiwan $(6.3 \mathrm{mg} / \mathrm{kg})$ but lower than the rest.

In order to calculate the intakes of the metals in this work, the percentage of each metal transferred to the infusion of tea according to the references consulted has been taken into account (Table 7). Since transfer data were not found in the literature consulted here for all of the types of tea studied, a value of $100 \%$ was given to the metal transfer in the cases where data was not found. This procedure was performed in such a way, by assuming the highest transfer value, in order to consider the case of maximum exposure to the metals studied for tea consumption. In other words, to consider the cases of maximum intake. The aim of this measure is to provide the maximum protection for the health of consumers. In cases where more than one transfer data for the same type of tea has been found and, also and as in the previous case, the highest consulted transfer value has been chosen to protect the health of consumers.

The total intakes of cadmium, cobalt, chromium, copper, iron, magnesium, nickel, lead and zinc from the consumption of black, green, white and red tea in the Canary Islands are shown in Table 8. The calculation of the intakes was based on a daily consumption of tea prepared with $100 \mathrm{ml}$ of boiling distilled water in which $2 \mathrm{~g}$ of tea were brewed for 5-10 minutes. Distilled water was used in the preparation of the different types of tea to prevent any interference from metals that may be present in drinking water.

The white tea provided the greatest intake of cadmium $(0.0764$ $\mu \mathrm{g} /$ day). The maximum intake of cobalt $(1.4 \mu \mathrm{g} /$ day $)$ came from the white tea and the minimum (of $0.2226 \mu \mathrm{g} /$ day) from the black tea. The greatest chromium intake was $5.12 \mu \mathrm{g} /$ day from the red tea and the lowest was $0.0645 \mu \mathrm{g} /$ day from the green tea. The red tea provided the largest intake of copper $(15.52 \mu \mathrm{g} /$ day $)$ and the lowest intake of copper came from the black tea $(2.4590 / \mathrm{d} \mu \mathrm{g}$ ay). The red and the green tea supplied the highest and lowest intakes of iron (14.3139 and $454.86 \mu \mathrm{g} /$ day, respectively). The highest intakes of magnesium and lead came from the white tea $(284.66$ and $0.3081 \mu \mathrm{g} /$ day, respectively), and lowest from the green tea $(26.3860$ and $0.0055 \mu \mathrm{g} /$ day, respectively). Red tea provided the highest intake of nickel $(7.74 \mu \mathrm{g} / \mathrm{day})$ and the lowest nickel intake came from the black tea $(2.8476 \mu \mathrm{g} /$ day $)$. Finally, the highest intake of zinc was from the white tea $(14.7 \mu \mathrm{g} / \mathrm{day})$, and this was similar to the zinc provided by the red tea $(14.4 \mu \mathrm{g} / \mathrm{day})$, while the black tea provided the lowest zinc intake $(0.9677 \mu \mathrm{g} /$ day $)$.

If the average consumption of tea by the Canary population is one cup ( $2 \mathrm{~g})$ per day, the contribution of these teas to the Dietary Reference Intakes (DRI) of chromium, copper, iron, magnesium and zinc should be taken into account. Although the DRI are dietary recommendations, both Canadian and American, to evaluate the intakes of the metals studied in the food groups of this work, they were selected here because they are the most recent established dietary guidelines.

The DRIs of chromium, copper, iron, magnesium and zinc for adults (men and women) are: $\mathrm{Cr} 20-35 \mathrm{ug} / \mathrm{day}, \mathrm{Cu} 700-900 \mathrm{ug} / \mathrm{day}$, 8-18 mg (8000-18000 ug) of Fe/day, 240-420 mg (240,000 to 420,000 ug) of Mg/day, 8-11 mg (8000-11000 ug) of $\mathrm{Zn} /$ day [60]. Therefore, the contributions to the DRIs (in percentage terms) involving established intakes of chromium, copper, iron, magnesium and zinc from the 
Citation: Gonzalez-Weller D, Rubio C, Gutiérrez AJ, Pérez B, Hernández-Sánchez C, et al.(2015) Dietary Content and Evaluation of Metals in Four Types of Tea (White, Black, Red and Green) Consumed by the Population of the Canary Islands. Pharm Anal Acta 6: 428. doi:10.4172/21532435.1000428

Page 5 of 10

\begin{tabular}{|c|c|c|c|c|c|c|c|c|c|}
\hline & $\mathrm{Cr}$ & Co & $\mathrm{Fe}$ & $\mathrm{Cu}$ & $\mathrm{Ni}$ & $\mathrm{Zn}$ & Mg & Cd & $\mathrm{Pb}$ \\
\hline $\mathrm{Cr}$ & 1 & -0.05 & $0.943^{* *}$ & 0.154 & $0.647^{\star * *}$ & $0.583^{\star *}$ & $0.281^{*}$ & $0.341^{\star *}$ & 0.198 \\
\hline Co & -0.05 & 1 & -0.138 & $-0.306^{\star *}$ & $0.254^{*}$ & $0.26^{*}$ & $0.349^{* *}$ & 0.151 & 0.213 \\
\hline $\mathrm{Fe}$ & $0.943^{* *}$ & -0.138 & 1 & $0.322^{* *}$ & $0.533^{* *}$ & $0.573^{* *}$ & 0.175 & $0.34^{* *}$ & 0.142 \\
\hline $\mathrm{Cu}$ & 0.154 & $-0.306^{\star *}$ & $0.322^{* *}$ & 1 & 0.017 & 0.13 & -0.158 & 0.033 & -0.064 \\
\hline $\mathrm{Ni}$ & $0.647^{* *}$ & $0.254^{*}$ & $0.533^{* *}$ & 0.017 & 1 & $0.614^{* *}$ & $0.500^{* *}$ & $0.33^{* *}$ & $0.385^{* *}$ \\
\hline $\mathrm{Zn}$ & $0.583^{* *}$ & $0.26^{*}$ & $0.573^{* *}$ & 0.13 & $0.614^{* *}$ & 1 & $0.623^{* *}$ & $0.504^{* *}$ & $0.477^{* *}$ \\
\hline $\mathrm{Mg}$ & $0.281^{*}$ & $0.349^{* *}$ & 0.175 & -0.158 & $0.5^{* *}$ & $0.623^{* *}$ & 1 & $0.475^{* *}$ & $0.556^{* *}$ \\
\hline $\mathrm{Cd}$ & $0.341^{* *}$ & 0.151 & $0.34^{* *}$ & 0.033 & $0.33^{* *}$ & $0.504^{\star *}$ & $0.475^{\star *}$ & 1 & $0.298^{* *}$ \\
\hline $\mathrm{Pb}$ & 0.198 & 0.213 & 0.142 & -0.064 & $0.385^{* *}$ & $0.477^{* *}$ & $0.556^{* *}$ & $0.298^{* *}$ & 1 \\
\hline
\end{tabular}

$*: p<0.05$

$* *: p<0.01$

Table 4: Pearson co-relation test.

\begin{tabular}{|c|c|c|c|}
\hline Metal & Population & Reference & Concentration $(\mathrm{mg} / \mathrm{kg})$ \\
\hline \multirow[t]{7}{*}{$\mathrm{Cd}$} & The Canary Islands & The present study & $<\mathrm{LOQ}^{1}$ \\
\hline & Japan & {$[55]$} & $0.018 \pm 0.0003$ \\
\hline & Turkey & {$[56]$} & $2.3 \pm 0.4$ \\
\hline & Taiwán & {$[57]$} & 0.07 \\
\hline & Saudi Arabia & [3] & 1.1 \\
\hline & India & [33] & 0.14 \\
\hline & Pakistan & {$[58]$} & 0.0121 \\
\hline \multirow[t]{6}{*}{ Co } & The Canary Islands & The present study & $0.44 \pm 0.09$ \\
\hline & Japan & {$[55]$} & $0.506 \pm 0.042$ \\
\hline & Turkey & {$[56]$} & $14.5 \pm 7.1$ \\
\hline & Taiwán & {$[57]$} & 0.2 \\
\hline & Saudi Arabia & {$[3]$} & 10.98 \\
\hline & Pakistan & {$[58]$} & 1.14 \\
\hline \multirow[t]{6}{*}{$\mathrm{Cr}$} & The Canary Islands & The present study & $0.38 \pm 0.15$ \\
\hline & Turkey & {$[56]$} & $13.0 \pm 1.7$ \\
\hline & Taiwan & {$[57]$} & 7.92 \\
\hline & Saudi Arabia & [3] & 9.8 \\
\hline & India & [33] & 4.76 \\
\hline & Pakistan & [58] & 12.63 \\
\hline \multirow[t]{7}{*}{$\mathrm{Cu}$} & The Canary Islands & The present study & $5.64 \pm 1.19$ \\
\hline & Japan & {$[55]$} & $27.7 \pm 0.7$ \\
\hline & Turkey & {$[56]$} & $16.5 \pm 3.9$ \\
\hline & Taiwan & [57] & 0.3 \\
\hline & Saudi Arabia & [3] & 18.1 \\
\hline & India & [33] & 24.07 \\
\hline & Pakistan & [58] & 21.39 \\
\hline \multirow[t]{5}{*}{$\mathrm{Fe}$} & The Canary Islands & The present study & $33.29 \pm 13.72$ \\
\hline & Japan & {$[55]$} & $134 \pm 48$ \\
\hline & Taiwan & {$[57]$} & 0.9 \\
\hline & Saudi Arabia & {$[3]$} & 250.46 \\
\hline & Pakistan & {$[58]$} & 118.46 \\
\hline \multirow[t]{3}{*}{$\mathrm{Mg}$} & The Canary Islands & The present study & $58.03 \pm 38.53$ \\
\hline & Japan & {$[55]$} & $2070 \pm 30$ \\
\hline & Taiwan & {$[57]$} & 135.3 \\
\hline \multirow[t]{6}{*}{$\mathrm{Ni}$} & The Canary Islands & The present study & $2.82 \pm 0.53$ \\
\hline & Japan & [55] & $8.06 \pm 0.19$ \\
\hline & Turkey & {$[56]$} & $23.3 \pm 9.6$ \\
\hline & Saudi Arabia & {$[3]$} & 16.8 \\
\hline & India & [33] & 2.53 \\
\hline & Pakistan & {$[58]$} & 6.78 \\
\hline \multirow[t]{7}{*}{$\mathrm{Pb}$} & The Canary Islands & The present study & $0.026 \pm 0.0259$ \\
\hline & Japan & {$[55]$} & $0.709 \pm 0.020$ \\
\hline & Turkey & {$[56]$} & $17.9 \pm 7.1$ \\
\hline & Taiwan & {$[57]$} & 2.01 \\
\hline & Saudi Arabia & [3] & 1 \\
\hline & India & [33] & 0.81 \\
\hline & Pakistan & [58] & 0.37 \\
\hline
\end{tabular}


Citation: Gonzalez-Weller D, Rubio C, Gutiérrez AJ, Pérez B, Hernández-Sánchez C, et al.(2015) Dietary Content and Evaluation of Metals in Four Types of Tea (White, Black, Red and Green) Consumed by the Population of the Canary Islands. Pharm Anal Acta 6: 428. doi:10.4172/21532435.1000428

Page 6 of 10

$\mathrm{Zn}$

\begin{tabular}{|c|}
\hline The Canary Islands \\
\hline Japan \\
\hline Turkey \\
\hline Taiwan \\
\hline Saudi Arabia \\
Pakistan \\
\hline
\end{tabular}

The present study

[55]

[56]

[57]

[3]

[58]
$5.04 \pm 0.81$

$36.6 \pm 0.7$

$129.0 \pm 12.9$

1.2

65.71

25.47

'LOQ: Quantification limit

Table 5: Comparison of the $\mathrm{Cd}, \mathrm{Co}, \mathrm{Cr}, \mathrm{Cu}, \mathrm{Fe}, \mathrm{Mg}, \mathrm{Ni}, \mathrm{Pb}$ and $\mathrm{Zn}$ concentrations in black tea: population of the Canary Islands against other populations

\begin{tabular}{|c|c|c|c|}
\hline Metal & Population & Reference & Concentration $(\mathrm{mg} / \mathrm{kg})$ \\
\hline \multirow[t]{4}{*}{$\mathrm{Cd}$} & The Canary Islands & The present study & $0.00775 \pm 0.01388$ \\
\hline & Japan & {$[59]$} & $0.0405 \pm 0.0041$ \\
\hline & Thailand & [32] & 0.035 \\
\hline & Taiwan & {$[57]$} & $\mathrm{ND}^{1}$ \\
\hline \multirow[t]{4}{*}{ Co } & The Canary Islands & The present study & $0.46 \pm 0.20$ \\
\hline & Japan & {$[59]$} & $0.226 \pm 0.004$ \\
\hline & Thailand & [32] & 0.294 \\
\hline & Taiwan & {$[57]$} & 0.7 \\
\hline \multirow[t]{3}{*}{$\mathrm{Cr}$} & The Canary Islands & The present study & $0.26 \pm 0.08$ \\
\hline & Thailand & [32] & 1.476 \\
\hline & Taiwan & {$[57]$} & 0.1 \\
\hline \multirow[t]{4}{*}{$\mathrm{Cu}$} & The Canary Islands & The present study & $8.40 \pm 4.5$ \\
\hline & Japan & [59] & $10.5 \pm 0.2$ \\
\hline & Thailand & [32] & 15.20 \\
\hline & Taiwan & {$[57]$} & 0.4 \\
\hline \multirow[t]{4}{*}{$\mathrm{Fe}$} & The Canary Islands & The present study & $65.66 \pm 26.77$ \\
\hline & Japan & {$[59]$} & $112 \pm 5$ \\
\hline & Thailand & [32] & 167.1 \\
\hline & Taiwan & [57] & 0.6 \\
\hline \multirow[t]{4}{*}{$\mathrm{Mg}$} & The Canary Islands & The present study & $38.13 \pm 19.79$ \\
\hline & Japan & [59] & $2200 \pm 60$ \\
\hline & Thailand & [32] & 2017 \\
\hline & Taiwan & [57] & 175.9 \\
\hline \multirow[t]{3}{*}{$\mathrm{Ni}$} & The Canary Islands & The present study & $2.31 \pm 0.54$ \\
\hline & Japan & {$[59]$} & $4.65 \pm 0.19$ \\
\hline & Thailand & [32] & 5.633 \\
\hline \multirow[t]{4}{*}{$\mathrm{Pb}$} & The Canary Islands & The present study & $0.03890 \pm 0.02292$ \\
\hline & Japan & {$[59]$} & $0.734 \pm 0.021$ \\
\hline & Thailand & [32] & 3.930 \\
\hline & Taiwan & [57] & 0.01 \\
\hline \multirow[t]{4}{*}{$\mathrm{Zn}$} & The Canary Islands & The present study & $5.16 \pm 1.11$ \\
\hline & Japan & {$[59]$} & $28.1 \pm 0.8$ \\
\hline & Thailand & [32] & 32.17 \\
\hline & Taiwan & {$[57]$} & 6.3 \\
\hline
\end{tabular}

${ }^{1} \mathrm{ND}$ : Not detected

Table 6: Comparison of the $\mathrm{Cd}, \mathrm{Co}, \mathrm{Cr}, \mathrm{Cu}, \mathrm{Fe}, \mathrm{Mg}, \mathrm{Ni}, \mathrm{Pb}$ and $\mathrm{Zn}$ concentrations in green tea: population of the the Canary Islands against other populations.

\begin{tabular}{|c|c|c|}
\hline Metal & Tipo de té & Porcentajes de transferencia \\
\hline \multirow[t]{4}{*}{$\mathrm{Cd}$} & Black & $40.3 \%[57]$ \\
\hline & Green & $14.18 \%[32]$ \\
\hline & White & $100 \%$ \\
\hline & Red & $100 \%$ \\
\hline \multirow[t]{5}{*}{ Co } & Black & $25.3 \%[57]$ \\
\hline & \multirow[t]{2}{*}{ Green } & $49.27 \%[32]$ \\
\hline & & $59.3 \%[57]$ \\
\hline & White & $100 \%$ \\
\hline & Red & $100 \%$ \\
\hline
\end{tabular}


Citation: Gonzalez-Weller D, Rubio C, Gutiérrez AJ, Pérez B, Hernández-Sánchez C, et al.(2015) Dietary Content and Evaluation of Metals in Four Types of Tea (White, Black, Red and Green) Consumed by the Population of the Canary Islands. Pharm Anal Acta 6: 428. doi:10.4172/21532435.1000428

Page 7 of 10

\begin{tabular}{|c|c|c|}
\hline \multirow[t]{5}{*}{$\mathrm{Cr}$} & Black & $67.5 \%[57]$ \\
\hline & \multirow[t]{2}{*}{ Green } & $11.45 \%[32]$ \\
\hline & & $12.4 \%[57]$ \\
\hline & White & $100 \%$ \\
\hline & Red & $100 \%$ \\
\hline \multirow[t]{5}{*}{$\mathrm{Cu}$} & Black & $21.8 \%[57]$ \\
\hline & \multirow[t]{2}{*}{ Green } & $12.96 \%$ [32] \\
\hline & & $22.9 \%[57]$ \\
\hline & White & $100 \%$ \\
\hline & Red & $100 \%$ \\
\hline \multirow[t]{5}{*}{$\mathrm{Fe}$} & Black & $30.9 \%[57]$ \\
\hline & \multirow[t]{2}{*}{ Green } & $2.39 \%[32]$ \\
\hline & & $10.9 \%[57]$ \\
\hline & White & $100 \%$ \\
\hline & Red & $100 \%$ \\
\hline \multirow[t]{5}{*}{$\mathrm{Mg}$} & Black & $50.6 \%[57]$ \\
\hline & \multirow[t]{2}{*}{ Green } & $34.26 \%$ [32] \\
\hline & & $34.6 \%[57]$ \\
\hline & White & $100 \%$ \\
\hline & Red & $100 \%$ \\
\hline \multirow[t]{4}{*}{$\mathrm{Ni}$} & Black & $50.49 \%[57]$ \\
\hline & Green & $67.71 \%$ [32] \\
\hline & White & $100 \%$ \\
\hline & Red & $100 \%$ \\
\hline \multirow[t]{5}{*}{$\mathrm{Pb}$} & Black & $58.6 \%[57]$ \\
\hline & \multirow[t]{2}{*}{ Green } & $7.11 \%[32]$ \\
\hline & & $7.1 \%[57]$ \\
\hline & White & $100 \%$ \\
\hline & Red & $100 \%$ \\
\hline \multirow[t]{5}{*}{$\mathrm{Zn}$} & Black & $9.6 \%[57]$ \\
\hline & \multirow[t]{2}{*}{ Green } & $32.15 \%$ [32] \\
\hline & & $60.7 \%[57]$ \\
\hline & White & $100 \%$ \\
\hline & Red & $100 \%$ \\
\hline
\end{tabular}

Table 7: Percentages of metals transferred to the brewed tea.

\begin{tabular}{|c|c|c|}
\hline Metal & Type of tea & Intake ( $\mu \mathrm{g} / \mathrm{day})$ \\
\hline \multirow[t]{4}{*}{$\mathrm{Cd}$} & Black & - \\
\hline & Green & 0.0022 \\
\hline & White & 0.0764 \\
\hline & Red & 0.0620 \\
\hline \multirow[t]{4}{*}{ Co } & Black & 0.2226 \\
\hline & Green & 0.5456 \\
\hline & White & 1.4000 \\
\hline & Red & 0.9000 \\
\hline \multirow[t]{4}{*}{$\mathrm{Cr}$} & Black & 0.5130 \\
\hline & Green & 0.0645 \\
\hline & White & 2.2400 \\
\hline & Red & 5.1200 \\
\hline \multirow[t]{4}{*}{$\mathrm{Cu}$} & Black & 2.4590 \\
\hline & Green & 3.8472 \\
\hline & White & 10.9200 \\
\hline & Red & 15.5200 \\
\hline \multirow[t]{4}{*}{$\mathrm{Fe}$} & Black & 20.5732 \\
\hline & Green & 14.3139 \\
\hline & White & 180.0000 \\
\hline & Red & 454.8600 \\
\hline
\end{tabular}


Citation: Gonzalez-Weller D, Rubio C, Gutiérrez AJ, Pérez B, Hernández-Sánchez C, et al.(2015) Dietary Content and Evaluation of Metals in Four Types of Tea (White, Black, Red and Green) Consumed by the Population of the Canary Islands. Pharm Anal Acta 6: 428. doi:10.4172/21532435.1000428

Page 8 of 10

\begin{tabular}{|c|c|c|}
\hline \multirow[t]{4}{*}{$\mathrm{Mg}$} & Black & 58.7264 \\
\hline & Green & 26.3860 \\
\hline & White & 284.6600 \\
\hline & Red & 199.9800 \\
\hline \multirow[t]{4}{*}{$\mathrm{Ni}$} & Black & 2.8476 \\
\hline & Green & 3.1282 \\
\hline & White & 6.7600 \\
\hline & Red & 7.7400 \\
\hline \multirow[t]{4}{*}{$\mathrm{Pb}$} & Black & 0.0305 \\
\hline & Green & 0.0055 \\
\hline & White & 0.3081 \\
\hline & Red & 0.2048 \\
\hline \multirow[t]{4}{*}{$\mathrm{Zn}$} & Black & 0.9677 \\
\hline & Green & 6.2642 \\
\hline & White & 14.7000 \\
\hline & Red & 14.4000 \\
\hline
\end{tabular}

Table 8: Intakes of $\mathrm{Cd}, \mathrm{Co}, \mathrm{Cr}, \mathrm{Cu}, \mathrm{Fe}, \mathrm{Mg}, \mathrm{Ni}, \mathrm{Pb}$ and $\mathrm{Zn}$ from the different types of tea.

consumption of $2 \mathrm{~g}$ of black, green, white and red tea per adult and day are shown in Table 9.

Furthermore, considering the abovementioned average consumption (one cup of tea $2 \mathrm{~g} /$ day), the contributions from the daily intake of the types of tea evaluated in this work to the Provisional Tolerable Monthly Intake (PTMI) of cadmium and Provisional Tolerable Weekly Intake (PTWI) of lead have been studied. In the case of cadmium, and because of its long half-life, the daily food intake has a small or even a negligible effect on the overall exposure. Therefore, and in order to assess the risks in the short or long term, the intake should be evaluated over a period of months, specifically, for at least one month. Thus, the Joint Expert Committee on Food Additives of $\mathrm{FAO} / \mathrm{WHO}$ decided to set the tolerable upper intake level of this metal as a monthly value of 25 micrograms / $\mathrm{kg}$ body weight $(3.17 \mathrm{mg} /$ day for an adult of $70 \mathrm{~kg}$ ) [61]. The PTWI value for lead will be $25 \mathrm{mg} / \mathrm{kg}$ body weight $(250 \mathrm{mg} /$ day for an adult of $70 \mathrm{~kg})$, although since 2011 this value has been outdated and we are waiting for the Committee to set a new PTWI value that is considered protective for people's health [61]. The contributions to the PTMI and PTWI for cadmium and lead (in percentage terms) are also shown in Table 9.

According to the above, a daily consumption of one cup of tea (2 g) by an adult makes a negligible contribution of the metals studied here, not only to the RDI, but also to the PTMI and PTWI. However, it is noteworthy that although the daily consumption of tea in the Canary population is relatively low, it should be borne in mind that there are other sources that may provide cadmium, chromium, copper, iron, magnesium, lead and zinc.

\section{Conclusion}

Iron was the most abundant metal in the four types of tea studied in the case of red tea, with a mean value of $227.43 \pm 68.39 \mathrm{mg} / \mathrm{kg}$, while the cadmium was the least abundant in black tea, whose value was not quantifiable. The intakes of chromium, copper, iron, magnesium and zinc found from the consumption of $2 \mathrm{~g}$ of black tea, green, white and red per adult per day, contribute little to the DRIs, with the maximum contribution being that of the chromium in the case of red tea, assuming $100 \%$ metal transfer to the brewed tea. The toxicological analysis revealed that the same consumption of $2 \mathrm{~g}$ of black, green, white and red tea per adult per day, contributes between 0069-1.956 \% of the PTMI of Cd and between $0002-0123 \%$ of the PTWI of Pb to an average person of $70 \mathrm{Kg}$. One, therefore, cannot suspect that there is a

\begin{tabular}{|c|c|c|c|c|}
\hline Metal & DRI ( $\mu$ g/day) & Type of tea & $\begin{array}{l}\text { Intake } \\
\text { day) }\end{array}$ & $\begin{array}{l}\text { Contribution to the } \\
\text { DRI (\%) }\end{array}$ \\
\hline \multirow[t]{4}{*}{$\mathrm{Cr}$} & \multirow[t]{4}{*}{$20-35$} & Black & 0.5130 & $1.466-2.565$ \\
\hline & & Green & 0.0645 & $0.184-0.322$ \\
\hline & & White & 2.2400 & $6.400-11.200$ \\
\hline & & Red & 5.1200 & $14.629-25.600$ \\
\hline \multirow[t]{4}{*}{$\mathrm{Cu}$} & \multirow[t]{4}{*}{$700-900$} & Black & 2.4590 & $0.273-0.351$ \\
\hline & & Green & 3.8472 & $0.427-0.550$ \\
\hline & & White & 10.9200 & $1.213-1.560$ \\
\hline & & Red & 15.5200 & $1.724-2.217$ \\
\hline \multirow[t]{4}{*}{$\mathrm{Fe}$} & \multirow[t]{4}{*}{$8000-18000$} & Black & 20.5732 & $0.114-0.257$ \\
\hline & & Green & 14.3139 & $0.080-0.179$ \\
\hline & & White & 180.0000 & $1.000-2.250$ \\
\hline & & Red & 454.8600 & $2.527-5.686$ \\
\hline \multirow[t]{4}{*}{$\mathrm{Mg}$} & \multirow[t]{4}{*}{$240000-420000$} & Black & 58.7264 & $0.014-0.024$ \\
\hline & & Green & 26.3860 & $0.006-0.011$ \\
\hline & & White & 284.6600 & $0.068-0.119$ \\
\hline & & Red & 199.9800 & $0.048-0.083$ \\
\hline \multirow[t]{4}{*}{$\mathrm{Zn}$} & \multirow[t]{4}{*}{$8000-11000$} & Black & 0.9677 & $0.009-0.012$ \\
\hline & & Green & 6.2642 & $0.057-0.078$ \\
\hline & & White & 14.7000 & $0.134-0.184$ \\
\hline & & Red & 14.4000 & $0.131-0.180$ \\
\hline Metal & PTMI ( $\mu g /$ day) & Type of tea & Intake ( $\mu \mathrm{g} /$ day) & $\begin{array}{l}\text { Contribution to the } \\
\text { PTMI (\%) }\end{array}$ \\
\hline \multirow[t]{4}{*}{$\mathrm{Cd}$} & \multirow[t]{4}{*}{3.17} & Black & - & - \\
\hline & & Green & 0.0022 & 0.069 \\
\hline & & White & 0.0764 & 2.410 \\
\hline & & Red & 0.0620 & 1.956 \\
\hline Metal & PTWI ( $\mu$ g/day) & Type of tea & $\begin{array}{l}\text { Intake } \\
\text { day) }\end{array}$ & $\begin{array}{l}\text { Contribution to the } \\
\text { PTWI (\%) }\end{array}$ \\
\hline \multirow[t]{4}{*}{$\mathrm{Pb}$} & \multirow[t]{4}{*}{250} & Black & 0.0305 & 0.012 \\
\hline & & Green & 0.0055 & 0.002 \\
\hline & & White & 0.3081 & 0.123 \\
\hline & & Red & 0.2048 & 0.082 \\
\hline
\end{tabular}

Table 9: Contribution to the DRIs from intakes of chrome, copper, iron, magnesium and zinc and to the PTMI and PTWI of cadmium and lead. 
Citation: Gonzalez-Weller D, Rubio C, Gutiérrez AJ, Pérez B, Hernández-Sánchez C, et al.(2015) Dietary Content and Evaluation of Metals in Four Types of Tea (White, Black, Red and Green) Consumed by the Population of the Canary Islands. Pharm Anal Acta 6: 428. doi:10.4172/21532435.1000428

toxic risk from the consumption of the different types of tea evaluated in this work, although it should be borne in mind that there are other sources that can provide the population of the Canary Islands with not only cadmium and lead, but also the other the metals studied here.

\section{Declaration of Interest}

Dr. Dailos González-Weller, corresponding author of the manuscript titled "Dietary content and evaluation of $\mathrm{Cd}, \mathrm{Co}, \mathrm{Cr}, \mathrm{Cu}$, $\mathrm{Fe}, \mathrm{Mg}, \mathrm{Ni}, \mathrm{Pb}$ and $\mathrm{Zn}$ in four types of tea (white, black, red and green) consumed by the population of the Canary Islands" declares that has not received any financial, consulting, and personal relationships with other people or organizations, writing assistance, grant support and numbers, and statements of employment that could influence this work.

\section{References}

1. Belitz HD, Grosch W (1997) Química de los alimentos. Acribia, Zaragoza.

2. Casares López R, García Olmedo R, Valls Pallés C (1978) Bromatology Treaty. Publications of the Department of Food Science, Technology and Applied Chemical Analysis (School of Pharmacy. Universidad Complutense) Madrid.

3. Ashraf W, Mian AA (2008) Levels of selected heavy metals in black tea varieties consumed in Saudi Arabia. Bull Environ Contam Toxicol 81: 101-104.

4. Fernández-Cáceres PL, Martín MJ, Pablos F, González AG (2001) Differentiation of tea (Camellia sinensis) varieties and their geographical origin according to their metal content. J Agric Food Chem 49: 4775-4779.

5. Mak JC (2012) Potential role of green tea catechins in various disease therapies: progress and promise. Clin Exp Pharmacol Physiol 39: 265-273.

6. Serafini M, Ghiselli A, Ferro-Luzzi A (1996) In vivo antioxidant effect of green and black tea in man. Eur J Clin Nutr 50: 28-32.

7. XuR, YeH, Sun Y, TuY, Zeng X (2012) Preparation, preliminary characterization, antioxidant, hepatoprotective and antitumor activities of polysaccharides from the flower of tea plant (Camellia sinensis). Food Chem Toxicol 50: 2473-2480.

8. Kuo KL, Weng MS, Chiang CT, Tsai YJ, Lin-Shiau SY, et al. (2005) Comparative studies on the hypolipidemic and growth suppressive effects of oolong, black, pu-erh, and green tea leaves in rats. J Agric Food Chem 53: 480-489.

9. Cao H, Qiao L, Zhang H, Chen J (2010) Exposure and risk assessment for aluminium and heavy metals in Puerh tea. Sci Total Environ 408: 2777-2784.

10. Kubota K, Sumi S, Tojo H, Sumi-Inoue Y, I-Chin H, et al. (2011) Improvements of mean body mass index and body weight in preobese and overweight Japanese adults with black Chinese tea (Pu-Erh) water extract. Nutr Res 31 421-428.

11. Butler LM, Wu AH (2011) Green and black tea in relation to gynecologic cancers. Mol Nutr Food Res 55: 931-940.

12. Banji D, Banji OJ, Abbagoni S, Hayath MS, Kambam S, et al. (2011) Amelioration of behavioral aberrations and oxidative markers by green tea extract in valproate induced autism in animals. Brain Res 1410: 141-151.

13. Chandra S, De Mejia Gonzalez E (2004) Polyphenolic compounds, antioxidant capacity, and quinine reductase activity of an aqueous extract of Ardisia compressa in comparison to mate (llex paraguensis) and green (Camellia sinensis) teas. J Agric Food Chem 52: 3583-3589.

14. Hamden K, Carreau S, Marki FA, Masmoudi H, El Feki A (2008) Positive effects of green tea on hepatic dysfunction, lipid peroxidation and antioxidant defence depletion induced by cadmium. Biol Res 41: 331-339.

15. Maron DJ, Lu GP, Cai NS, Wu ZG, Li YH, et al. (2003) Cholesterol-lowering effect of a theaflavin-enriched green tea extract: a randomized controlled trial. Arch Intern Med 163: 1448-1453.

16. Hasegawa R, Chujo T, Sai-Kato K, Umemura T, Tanimura A, et al. (1995) Preventive effects of green tea against liver oxidative DNA damage and hepatotoxicity in rats treated with 2-nitropropane. Food Chem Toxicol 33: 961-970.

17. Dulloo AG, Seydoux J, Girardier L, Chantre P, Vandermander J (2000) Green tea and thermogenesis: interactions between catechin-polyphenols, caffeine and sympathetic activity. Int J Obes Relat Metab Disord 24: 252-258.
18. Thavanesan $N$ (2011) The putative effects of green tea on body fat: an evaluation of the evidence and a review of the potential mechanisms. $\mathrm{Br} \mathrm{J}$ Nutr 106: $1297-1309$

19. Fujiki H (2005) Green tea: Health benefits as cancer preventive for humans Chem Rec 5: 119-132.

20. Bettuzzi S, Brausi M, Rizzi F, Castagnetti G, Peracchia G, et al. (2006) Chemoprevention of human prostate cancer by oral administration of green tea catechins in volunteers with high-grade prostate intraepithelial neoplasia: a preliminary report from a one-year proof-of-principle study. Cancer Res 66 : 1234-1240.

21. Sagesaka-Mitane Y, Miwa M, Okada S (1990) Platelet aggregation inhibitors in hot water extract of green tea. Chem Pharm Bull (Tokyo) 38: 790-793.

22. Almajano MP, Vila I, Gines S (2011) Neuroprotective effects of white tea against oxidative stress-induced toxicity in striatal cells. Neurotox Res 20: 372-378.

23. López V, Calvo MI (2011) White tea (Camellia sinensis Kuntze) exerts neuroprotection against hydrogen peroxide-induced toxicity in PC12 cells. Plant Foods Hum Nutr: 66: 22-26.

24. Santana-Rios G, Orner GA, Amantana A, Provost C, Wu SY, et al. (2001) Potent antimutagenic activity of white tea in comparison with green tea in the Salmonella assay. Mutat Res 495: 61-74.

25. Mao JT, Nie WX, Tsu IH, Jin YS, Rao JY, et al. (2010) White tea extract induces apoptosis in non-small cell lung cancer cells: the role of peroxisome proliferator-activated receptor-\{gamma\} and 15-lipoxygenases. Cancer Prev Res (Phila) 3: 1132-1140.

26. Camouse MM, Domingo DS, Swain FR, Conrad EP, Matsui MS, et al. (2009) Topical application of green and white tea extracts provides protection from solar-simulated ultraviolet light in human skin. Exp Dermatol 18: 522-526.

27. Okello EJ, Leylabi R, McDougall GJ (2012) Inhibition of acetylcholinesterase by green and white tea and their simulated intestinal metabolites. Food Funct 3: 651-661.

28. Malerba S, Galeone C, Pelucchi C, Turati F, Hashibe M, et al. (2013) A metaanalysis of coffee and tea consumption and the risk of glioma in adults. Cancer Causes Control 24: 267-276.

29. Hamao M, Matsuda H, Nakamura S, Nakashima S, Semura S, et al. (2011) Anti-obesity effects of the methanolic extract and chakasaponins from the flower buds of Camellia sinensis in mice. Bioorg Med Chem 19: 6033-6041.

30. Yang CS, Wang H, Li GX, Yang Z, Guan F, et al. (2011) Cancer prevention by tea: Evidence from laboratory studies. Pharmacol Res 64: 113-122.

31. Gutiérrez AJ, González-Weller D, González T, Burgos A, Lozano G, et al. (2007) Content of toxic heavy metals (mercury, lead, and cadmium) in canned variegated scallops (Chlamys varia). J Food Prot 70: 2911-2915.

32. Nookabkaew S, Rangkadilok N, Satayavivad J (2006) Determination of trace elements in herbal tea products and their infusions consumed in Thailand. J Agric Food Chem 54: 6939-6944.

33. Seenivasan S, Manikandan N, Nair Muraleedharan NN, Selvasundaram R (2008) Heavy metal content of black teas from south India. Food Control 19: 746-749.

34. Rubio C, Lucas JRD, Gutiérrez AJ, Glez-Weller D, Pérez Marrero B, et al. (2012) Evaluation of metal concentrations in mentha herbal teas (Mentha piperita, Mentha pulegium and Mentha species) by inductively coupled plasma spectrometry. J Pharm Biomed Anal 71: 11-17

35. Frías I, Rubio C, González-Iglesias T, Gutiérrez AJ, González-Weller D, et al. (2008) "Metals in fresh honeys from Tenerife Island, Spain". Bull Environ Contam Toxicol 80: 30-33.

36. Rubio C, González-Iglesias T, Revert C, Reguera JI, Gutiérrez AJ, et al. (2005) Lead dietary intake in a Spanish population (Canary Islands). J Agric Food Chem 53: 6543-6549.

37. González-Weller D, Karlsson L, Caballero A, Hernández F, Gutiérrez A, et al. (2006) Lead and cadmium in meat and meat products consumed by the population in Tenerife Island, Spain. Food Addit Contam 23: 757-763.

38. Vallet M, Faus J, García-España E, Moratal J (2003) Introduction to bioinorganic chemistry. Editorial Synthesis, Madrid.

39. Anderson RA, Roussel AM, Zouari N, Mahjoub S, Matheau JM, et al. (2001) Potential antioxidant effects of zinc and chromium supplementation in people with type 2 diabetes mellitus. J Am Coll Nutr 20: 212-218. 
Citation: Gonzalez-Weller D, Rubio C, Gutiérrez AJ, Pérez B, Hernández-Sánchez C, et al.(2015) Dietary Content and Evaluation of Metals in Four Types of Tea (White, Black, Red and Green) Consumed by the Population of the Canary Islands. Pharm Anal Acta 6: 428. doi:10.4172/21532435.1000428

40. González-Weller D, Rubio C, Gutiérrez AJ, Luis González G, Caballero Mesa JM, et al. (2013) Dietary intake of barium, bismuth, chromium, lithium, and strontium in a Spanish population (Canary Islands, Spain). Food Chem Toxico 62: 856-858.

41. Lai IK, Klaren WD, Li M, Wels B, Simmons DL, et al. (2013) Does dietary copper supplementation enhance or diminish PCB126 toxicity in the rodent liver? Chem Res Toxicol 26: 634-644

42. González-Weller D, Caballero Mesa A, Karlsson L, Hernández F, Gutiérrez Fernández AJ, et al. (2014) Determination of iron, copper, zinc and manganese in sausage, poultry-rabbit meat, viscera and red meats consumed by the population in the Canary Islands, Spain. J Toxins 1: 1-7.

43. Gottfried RJ, Gering JP, Machell K, Yenokyan G, Riddle MA (2013) The Iron Status of Children and Youth in a Community Mental Health Clinic is lower than that of a National Sample. J Child Adolesc Psychopharmacol 23: 91-100.

44. Ford ES (1999) Serum magnesium and ischaemic heart disease: findings from a national sample of US adults. Int J Epidemiol 28: 645-651.

45. Wicks TC (1999) AANA Journal course: update for nurse anesthetists-magnesium homeostasis and deficiency. AANA J 67: 171-179.

46. Gums JG (2004) Magnesium in cardiovascular and other disorders. Am J Health Syst Pharm 61: 1569-1576.

47. González-Weller D, Gutiérrez ÁJ, Rubio C, Revert C, Hardisson A (2012) A total diet study of nickel intake in a Spanish population (Canary Islands). Int J Food Sci Nutr 63: 902-912.

48. Ala S, Shokrzadeh M, Golpour M, Salehifar E, Alami M, et al. (2013) Zinc and copper levels in Iranian patients with psoriasis: a case control study. Biol Trace Elem Res 153: 22-27.

49. Rubio C, Hardisson A, Reguera JI, Revert C, Lafuente MA, et al. (2006) Cadmium dietary intake in the Canary Islands, Spain. Environ Res 100: 123-129.

50. Nair AR, Degheselle O, Smeets K, Van Kerkhore E, Cuyppers A (2013) Cadmium-induced Pathologies: Where is the Oxidative Balance Lost (or Not)? Int J Md Sci 14: 6116-6143.
51. Lloyd A Currie (1995) Nomenclature in Evaluation of Analytical Methods including Detection and Quantificaction Capabilities: (IUPAC Recommendations 1995). Analytica Chimica Acta 391: 105-126.

52. Xu P, Huang SL, Zhu RH, Han XM, Zhou HH (2002) Phenotypic polymorphism of CYP2A6 activity in a Chinese population. Eur J Clin Pharmacol 58: 333-337.

53. Pan G (2002) Confidence intervals for comparing two scale parameters based on Levene's statistics. J Nonparametr Stat 4: 459-476.

54. Reilly C (2002) Metal contamination of food. Its significance for food quality and human health (3rd edn) Blackwell Science Ltd, United Kingdom.

55. Matsuura H, Hokura A, Katsuki F, Itoh A, Haraguchi H (2001) Multielement determination and speciation of major-to-trace elements in black tea leaves by ICP-AES and ICP-MS with the aid of size exclusion chromatography. Anal Sc 17: 391-398.

56. Narin I, Colak H, Turkoglu O, Soylak M, Dogan M (2004) Heavy metals in black tea samples produced in Turkey. Bull Environ Contam Toxicol 72: 844-849.

57. Shen FM, Chen HW (2008) Element composition of tea leaves and tea infusions and its impact on health. Bull Environ Contam Toxicol 80: 300-304.

58. Soomro MT, Zahir E, Mohiuddin S, Khan AN, Naqvi II (2008) Quantitative assessment of metals in local brands of tea in Pakistan. Pak J Biol Sci 11: 285-289.

59. Matsuura $H$, Hokura A, Haraguchi $H(2000)$ Multielement determination and speciation of major-to-ultratrace elements in green tea leaves by ICP-MS and ICP-AES. Bunseki Kagaku 49: 397-404.

60. Trumbo P, Yates AA, Schlicker S, Poos M (2001) Dietary Reference Intakes for Arsenic, Boron, Chromium, Copper, lodine, Iron, Manganese, Molybdenum, Nickel, Silicon, Vanadium, and Zinc. J Am Diet Assoc 101: 294-301.

61. WHO (2011) Evaluation on certain food additives and contaminants. 73rd report of the Joint FAO/WHO Expert Committee on Food Additive. WHO Technical Report Series 960. FAO/WHO, Rome, Italy. 